\title{
Postawy pielęgniarek wobec umierania i śmierci pacjenta
}

\author{
Nurses, attitude towards patient dying death
}

BEATA PONIŃSKA ${ }^{1}$, GRAŻYNA CHOJNACKA-KOWALEWSKA ${ }^{1,2}$

1Wojewódzki Szpital Specjalistyczny im. Błogosławionego księdza Jerzego Popiełuszki
we Włocławku, Oddział Medycyny Paliatywnej
2Państwowa Uczelnia Zawodowa we Włocławku, Instytut Nauk o Zdrowiu

DOI: http://dx.doi.org/10.21784/lwP.2020.003

ISSN: 2451-1846

\section{Streszczenie:}

Wstęp. Śmierć pacjentów jest nieuniknionym elementem w pracy pielęgniarek. Wiąże się z przeżywaniem różnorodnych emocji co wpływa na ich system wartości i życie osobiste.

Cel. Celem niniejszej pracy było badanie postaw pielęgniarek wobec pacjentów umierających, przedstawienie ich emocji, lęku i przeżyć związanych ze śmiercią pacjentów oraz ocena wpływu na życie osobiste badanych.

Metody i materiał. Wyniki badań własnych omówione są na podstawie ankiety przeprowadzonej w grupie 100 pielęgniarek oraz narzędzia wystandaryzowanego Mini-COPE.

Wyniki. Stan cywilny i wykształcenie nie różnicują postaw pielęgniarek wobec umierania i śmierci pacjenta. Natomiast wiek oraz staż pracy okazał się czynnikiem istotnie różnicującym zmianę hierarchii wartości po śmierci pacjenta i wpływał dodatnio na poziom stresu.

Wnioski. Kontakt pielęgniarek z pacjentami umierającymi naraża na stres, negatywne emocje, duże obciążenie psychiczne. Zdolność współczucia, odpowiednie przygotowanie pielęgniarek ma duży wpływ na zapewnienie zmniejszenia cierpienia i godnego umierania pacjenta. 
Słowa kluczowe: umieranie, śmierć, cierpienie, pacjent, postawy pielęgniarek, emocje pielęgniarek, wartości, hierarchia

\begin{abstract}
:
Introduction. Patient death is an unavoidable element in the work of nurses. It is associated with experiencing various emotions which affects their value system and personal life.

The aim. To examine the attitudes of nurses towards dying patients, to present their emotions, anxiety and experiences related to patients' deaths and to assess the impact on the personal life of the respondents.

Methods and research material. The results of own research based on the questionnaire as well as the standardized Mini-COPE tool.

Results. Gender, marital status and education do not differentiate the attitudes of nurses towards the dying and death of the patient. On the other hand, age and seniority turned out to be a factor that significantly differentiated the change in the hierarchy of values after the patient's death and had a positive effect on the level of stress.

Conclusions. Summing up this work, it should be noted that the contact of nurses with dying patients exposes them to stress, negative emotions and high psychological burden. Their hierarchy of values changed after the patient's death. The ability to sympathize and proper preparation of nurses has a great impact on ensuring the reduction of suffering and the patient's dying.
\end{abstract}

Keywords: dying, death, suffering, patient, nurses' attitudes, emotions of nurses, values, hierarchy

\title{
Wstęp
}

Społeczno-kulturowy i religijny aspekt śmierci uznaje się powszechnie za przejście do innego wymiaru. Zarówno ci, którzy deklarują swoją przynależność do religii jak i ci, którzy określają siebie mianem niewierzących zgadzają się co do 
poglądu, ze śmierć jest tylko etapem między życiem tu na Ziemi a życiem w innym wymiarze. Trudno jest zaakceptować definitywne i jednoznaczne odejście $\mathrm{z}$ tego świata i dlatego nadaje się śmierci znaczenie metafizyczne poprzez poszukiwanie uzasadnienia w różnych religiach i filozofiach [1].

Nie jest łatwo traktować ją jako naturalny i nieunikniony kres naszego życia, stąd z jednej strony staramy się do tego podchodzić racjonalnie, $\mathrm{z}$ drugiej, jeśli dotyka ona nas bezpośrednio szukamy wytłumaczenia i sposobu aby ją od siebie odsunąć.[2] Człowiek od zawsze starał się „oswoić" śmierć i emocje z nią związane i nadać odchodzeniu wyjątkowe znaczenie. Śmierć stanowiła zwieńczenie i dopełnienie życia, należała się jej więc odpowiednia celebracja [1].

Proces umierania jest doświadczeniem trudnym i bolesnym dla wszystkich, zarówno dla rodziny jak i chorego, ale również dla personelu medycznego. Każda z osób, która ma styczność $\mathrm{z}$ umierającym jest $\mathrm{w}$ innej sytuacji i wiążą ją inne relacje z pacjentem. Od pielęgniarek oczekuje się kompetencji, taktu i empatii, oczekuje tego zarówno chory jaki i osoby bliskie pacjenta. Obie strony wymagają wsparcia psychologicznego określanego jako „leczenie przez rozmowę”. Osoby wspierające bliskich chorych umierających jak i samych chorych muszą nauczyć się postępować tak, aby wszyscy czuli ich życzliwość, wyrozumiałość, szacunek i zaufanie[3].

Umieranie chorego jest na ogół powolnym procesem, przechodzącym przez kolejne etapy. Zwykle w tak zwanych ostatnich miesiącach, dniach życia chorego przede wszystkim zmniejsza się zainteresowanie światem zewnętrznym. Chory 
dokonuje swoistego bilansu, rozmyśla nad swoim życiem, wspomina i ocenia jak żył, czego żałuje, a z czego jest dumny. Stara się też doprowadzić do końca niepozałatwiane sprawy. Traci zainteresowanie sprawami codziennymi i pogrąża się w analizowaniu przeszłości. Poza zmianami osobowościowymi zachodzą również objawy fizjologiczne, takie jak zmniejszony apetyt, trudności w połykaniu, postępujące chudnięcie, zmęczenie i osłabienie oraz częstsze i dłuższe podsypianie, zaburzona orientacja w czasie. Chory może wtedy prosić o eutanazję, gdyż boi się bólu, ale może też obawiać się utraty godności, z czego nie zawsze zdają sobie sprawę najbliżsi [4].

Pielęgniarki są szczególnie narażone na kontakt z ciężko chorymi i związanym z tym zjawiskiem śmierci. Postawa jaką prezentują wynika nie tylko $\mathrm{z}$ profesjonalizmu będącego efektem szkolenia zawodowego i doświadczenia ale również cech charakterologicznych i wrażliwości. Jak powinna zachować się pielęgniarka, która na co dzień spotyka się z procesem umierania, lękiem przed odchodzeniem pacjenta i bólem najbliższych jest tematem wielu dyskusji i opracowań. Prawidłowe podejście do osób znajdujących się w tej trudnej sytuacji powinno polegać na normalizacji przeżyć i poradzeniu sobie z własnymi emocjami, zwłaszcza z lękiem związanym z utratą pacjenta oraz złością i poczuciem braku skuteczności podejmowanych działań mających na celu ratowanie życia chorego [5].

Wydawać się może, że wcale nie tak trudno zobojętnieć, gdy na każdym kroku spotykamy się z cierpieniem, śmiercią, gdy te zjawiska stają się „,chlebem powszednim”. Jak każdy człowiek, 
pielęgniarka z całą pewnością odczuwa lęk, nie da się od tego tak po prostu odciąć ale też nie można śmierci pacjenta traktować jako porażki. Trzeba mieć „czyste sumienie” i zrobić wszystko co można.

Zetknięcie się pierwszy raz z czyjąś śmiercią odruchowo sprowadza myśli pracujących wokół chorego ludzi, w tym pielęgniarek, na tory egzystencjonalne: o sensie istnienia, o końcu życia, o tym co nas czeka po drugiej stronie. 0 ile jeszcze zmarły był człowiekiem starszym, schorowanym tłumaczy się tą śmierć „inaczej”, że tak może dla chorego lepiej, że już przynajmniej się nie męczy. Szok emocjonalny jest wtedy mniejszy, niż w przypadku gdy umierającym pacjentem jest dziecko. Śmierć dziecka może wywołać wstrząs psychiczny szczególnie wtedy, gdy pielęgniarka je dobrze znała, opiekowała się i zżyła się z nim. W takich sytuacjach nabiera się szacunku do życia, szanuje się każdą chwilę i z każdej się cieszy [6].

Proces umierania i śmierci jest bardzo trudny tak dla pacjenta, jego rodziny, a także personelu medycznego. Jednym ze sposobów radzenia sobie $\mathrm{z}$ tym problemem jest przyjmowanie różnych postaw. W poglądach psychologów można znaleźć różne podejścia do problematyki postaw w zależności od przyjmowanej myśli teoretycznej. Dlatego też jedni zwracają uwagę na aspekt intelektualny, inni dostrzegają płaszczyznę życia emocjonalnego, a jeszcze inni definiują postawy uwypuklając aspekt działania. Wagę temu problemowi nadaje fakt, że coraz częściej większość ludzi umiera samotnie w szpitalu, bez obecności osób bliskich, dlatego też znaczącą rolę może odgrywać personel medyczny. Jego ranga jest bardzo 
ważna zarówno z punktu widzenia przedłużenia życia w sensie biologicznym, jak również podniesienia jakości życia pacjenta, tak aby było one jak najbardziej zbliżone do tego, jakie charakterystyczne jest dla osób zdrowych. Większość pacjentów nie spodziewa się cudu wyleczenia lecz doznaje potrzeby bezpieczeństwa, troski, życzliwości, opieki do końca swoich chwil. Niezbędna więc staje się pomoc z zewnątrz. Cierpienie i śmierć pacjentów jest jednym z największych problemów $\mathrm{z}$ jakimi spotykają się pielęgniarki w swojej pracy zawodowej. Podstawową rolą wobec umierających powinno być takie działanie, które pozwoli godnie przejść przez ten proces zarówno choremu jak i osobom sprawującym nad nim opiekę. Ważnym elementem postępowania wobec chorego jest jego poznanie i podejmowanie czynności zindywidualizowanych, wynikających z potrzeb. Chodzi tu nie tylko o rozpoznanie czysto medyczne, ale także poznanie chorego jako człowieka [7].Kontakt z umierającym pacjentem jest źródłem wielu doświadczeń mających wpływ na postrzeganie zarówno życia jak i śmierci przez osoby sprawujące opiekę. W naszej kulturze przeważają negatywne postawy wobec śmierci, a pielęgniarki w związku z wykonywanym zawodem częściej niż inni obcują ze śmiercią i dlatego częściej narażone są na ich oddziaływanie.

\section{Cel}

Celem badań przeprowadzonych na potrzeby niniejszej pracy była ocena postaw pielęgniarek wobec umierania i śmierci pacjenta. 


\section{Materiał i metody}

$\mathrm{W}$ badaniach na temat postaw pielęgniarki/pielęgniarza wobec umierania i śmierci pacjenta udział wzięło 100 osób. Były to osoby na co dzień zajmujące się osobami w stanie ciężkim lub umierającymi.

W badaniu większość stanowiły kobiety - pielęgniarki (91\%), a pozostałe 9\% to mężczyźni - pielęgniarze.

Analizując grupę pod względem wieku zauważa się, że największy odsetek to osoby w wieku od 41 do 50 lat (38\%), $26 \%$ stanowili badani w wieku od 51 do 60 lat, a o 1 p.p mniej to osoby od 31 do 40 roku życia. Co dziesiąty ankietowany miał poniżej 30 lat, a 1\% powyżej 60 lat.

W badanej grupie połowa badanych była w związku małżeńskim, a $19 \%$ to osoby stanu wolnego. Ponadto $16 \%$ reprezentowały osoby rozwiedzione, a $8 \%$ osoby w wolnym związku partnerskim. W grupie znalazło się także 6\% wdów/wdowców.

$\mathrm{Z}$ danych wynika, że większość badanych legitymowała się wykształceniem na poziomie licencjata - 55\%, a stopień magistra miało 29\% respondentów. Pozostałe 16\% miało wykształcenie zawodowe pielęgniarskie.

$\mathrm{Z}$ badan wynika, że największy odsetek badanych to osoby doświadczone mające powyżej 25 lat stażu pracy w zawodzie pielęgniarki/pielęgniarza - 36\%. Druga pod względem liczebności grupa pracowała w zawodzie od 21 do 25 lat (17\%), a trzecia od 16 do 20 lat (14\%). 11\% respondentów miało staż pracy od6 do 10 lat, a o 2 p.p. mniej od 11 do 15 lat. Pozostali pracowali w zawodzie od 1 do 5 lat lub poniżej 1 roku. 
W celu obliczania różnic międzygrupowych badanych w dalszej analizie podzielono na trzy grupy różniące się stażem pracy: do 5 lat, od 6 do 25 lat oraz powyżej 25 lat. Badanych podzielono umownie na trzy grupy ze względu na posiadany staż. W grupie pierwszej znalazło się $13 \%$ badanych i były to osoby najkrócej związane z zawodem; w grupie drugiej osoby od 6 do 25 lat pracy stanowiące 51\% grupy, a w grupie trzeciej badani o najdłuższym stażu pracy, tj. powyżej 25 lat 36\%.

W związku z wybraną metodą, na potrzeby badań wykorzystano technikę ankiety, której narzędziem jest kwestionariusz ankiety oraz narzędzie wystandaryzowane Mini-COPE.

Do opracowania wyników badań przeprowadzonych badań w sposób statystyczny oraz zweryfikowania postawionych wcześniej hipotez zastosowane zostały wykorzystany rozkład liczbowy, rozkład procentowy, test $\mathrm{t}$ dla prób niezależnych, test $\mathrm{chi}^{2}$, test jednoczynnikowej ANOVA oraz korelacja r-Pearsona.

\section{Wyniki}

Pierwszym celem badań było poznanie najważniejszych wartości badanych pielęgniarek i pielęgniarzy. Rozkład liczbowy i procentowy odpowiedzi zawiera tabela 1 .

Tab. 1. Najważniejsze wartości badanych.

\begin{tabular}{|l|l|l|l|}
\hline \multicolumn{2}{|c|}{} & $\mathrm{n}$ & $\%$ \\
\hline \multirow{4}{*}{ Ważne } & zdrowie & 60 & 60,0 \\
\cline { 2 - 4 } & rodzina & 31 & 31,0 \\
\cline { 2 - 4 } & przyjaźń & 7 & 7,0 \\
\cline { 2 - 4 } & pomoc innym & 2 & 2,0 \\
\hline
\end{tabular}




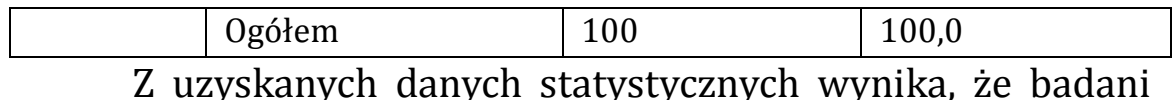
najbardziej cenią zdrowie (60\%) oraz rodzinę (31\%). Wśród pozostałych najważniejszych wartości znalazła się przyjaźń wskazana przez $7 \%$ badanych i pomoc innym, która wybrana została przez $2 \%$ respondentów.

W dalszej części sprawdzono czy dane socjodemograficzne różnicują najważniejsze wartości badanych. Wyniki częstości i testu chi ${ }^{2}$ różnic $\mathrm{w}$ hierarchii wartości ze względu na płeć przedstawia tabela 2 .

Tab. 2. Najważniejsze wartości a płeć.

\begin{tabular}{|c|c|c|c|c|c|}
\hline & \multicolumn{2}{|l|}{ Płeć } & \multirow[t]{2}{*}{ Ogółem } \\
\hline & & & kobieta & mężczyzna & \\
\hline \multirow[t]{8}{*}{ Wartości } & \multirow[t]{2}{*}{ zdrowie } & Liczebność & 57 & 3 & 60 \\
\hline & & \% z Płeć & $62,6 \%$ & $33,3 \%$ & $60,0 \%$ \\
\hline & \multirow[t]{2}{*}{ rodzina } & Liczebność & 28 & 3 & 31 \\
\hline & & \% z Płeć & $30,8 \%$ & $33,3 \%$ & $31,0 \%$ \\
\hline & \multirow[t]{2}{*}{ przyjaźń } & Liczebność & 4 & 3 & 7 \\
\hline & & \% z Płeć & $4,4 \%$ & $33,3 \%$ & $7,0 \%$ \\
\hline & \multirow{2}{*}{$\begin{array}{l}\text { pomoc } \\
\text { innym }\end{array}$} & Liczebność & 2 & 0 & 2 \\
\hline & & \% z Płeć & $2,2 \%$ & , 0\% & $2,0 \%$ \\
\hline \multirow{2}{*}{\multicolumn{2}{|c|}{ Ogółem }} & Liczebność & 91 & 9 & 100 \\
\hline & & \% z Płeć & $100,0 \%$ & $100,0 \%$ & $100,0 \%$ \\
\hline
\end{tabular}

Z danych statystycznych wynika, że kobiety częściej niż mężczyźni cenili sobie zdrowie (62,2\% do 33,3\%), a u mężczyźni częściej niż kobiety wskazywali na wartość przyjaźń jako ważną w ich życiu (33,3\% do 4,4\%). Różnice były istotne statystycznie ( $\mathrm{p}=0,011)$. 
Wyniki częstości i testu chi ${ }^{2}$ badającego różnice między zmianą hierarchii wartości po śmierci pacjenta a płcią badanych przedstawia tabela 3.

Tab. 3. Zmiana hierarchii wartości po śmierci pacjenta a płeć.

\begin{tabular}{|c|c|c|c|c|c|c|}
\hline & & & & Płeć & & Ogółem \\
\hline & & & & kobieta & mężczyzna & \\
\hline Zmiana & hierarchii & tak & $\mathrm{N}$ & 37 & 2 & 39 \\
\hline wartości & & & $\%$ & $40,7 \%$ & $22,2 \%$ & $39,0 \%$ \\
\hline & & nie & $\mathrm{N}$ & 27 & 5 & 32 \\
\hline & & & $\%$ & $29,7 \%$ & $55,6 \%$ & $32,0 \%$ \\
\hline & & nie & $\mathrm{N}$ & 27 & 2 & 29 \\
\hline & & wiem & $\%$ & $29,7 \%$ & $22,2 \%$ & $29,0 \%$ \\
\hline Ogółem & & & $\mathrm{N}$ & 91 & 9 & 100 \\
\hline & & & $\%$ & $100,0 \%$ & $100,0 \%$ & $100,0 \%$ \\
\hline
\end{tabular}

Nie wykazano istotnych różnic w zmianie hierarchii wartości po śmierci pacjenta a płcią pielęgniarek/pielęgniarzy ( $p>0,05)$. Wyniki częstości i testu chi $^{2}$ różnic $w$ hierarchii wartości ze względu na wiek przedstawia tabela 4.

Tab. 4. Najważniejsze wartości a wiek

\begin{tabular}{|c|c|c|c|c|c|c|c|c|}
\hline & \multicolumn{5}{|l|}{ Wiek } & \multirow{2}{*}{$\begin{array}{l}\text { Ogół } \\
\text { em }\end{array}$} \\
\hline & & & $\begin{array}{l}\text { poniżej } \\
30 \text { lat }\end{array}$ & $\begin{array}{ll}\text { od } & 31 \\
\text { do } & 40 \\
\text { lat } & \end{array}$ & $\begin{array}{ll}\text { od } & 41 \\
\text { do } & 50 \\
\text { lat } & \end{array}$ & $\begin{array}{ll}\text { od } & 51 \\
\text { do } & 60 \\
\text { lat } & \end{array}$ & $\begin{array}{l}\text { powyżej } \\
60 \text { lat }\end{array}$ & \\
\hline \multirow{8}{*}{$\begin{array}{l}\text { Wartoś } \\
\text { ci }\end{array}$} & \multirow[t]{2}{*}{ zdrowie } & $\mathrm{n}$ & 5 & 16 & 25 & 13 & 1 & 60 \\
\hline & & $\%$ & $50,0 \%$ & $64,0 \%$ & $65,8 \%$ & $50,0 \%$ & $100,0 \%$ & $\begin{array}{l}60,0 \\
\%\end{array}$ \\
\hline & \multirow[t]{2}{*}{ rodzina } & $\mathrm{n}$ & 3 & 5 & 11 & 12 & 0 & 31 \\
\hline & & $\%$ & $30,0 \%$ & $20,0 \%$ & $28,9 \%$ & $46,2 \%$ &, $0 \%$ & $\begin{array}{l}31,0 \\
\%\end{array}$ \\
\hline & \multirow[t]{2}{*}{ przyjaźń } & $n$ & 2 & 2 & 2 & 1 & 0 & 7 \\
\hline & & $\%$ & $20,0 \%$ & $8,0 \%$ & $5,3 \%$ & $3,8 \%$ & ,0\% & $7,0 \%$ \\
\hline & \multirow{2}{*}{$\begin{array}{l}\text { pomoc } \\
\text { innym }\end{array}$} & $\mathrm{n}$ & 0 & 2 & 0 & 0 & 0 & 2 \\
\hline & & $\%$ & , $0 \%$ & $8,0 \%$ & , $0 \%$ & , $0 \%$ & , 0\% & $2,0 \%$ \\
\hline \multirow{2}{*}{\multicolumn{2}{|c|}{ Ogółem }} & $\mathrm{n}$ & 10 & 25 & 38 & 26 & 1 & 100 \\
\hline & & $\%$ & $100,0 \%$ & $100,0 \%$ & $100,0 \%$ & $100,0 \%$ & $100,0 \%$ & 100,0 \\
\hline
\end{tabular}


opinie $\mathrm{w}$ tej kwestii miały pielęgniarki i pielęgniarze $\mathrm{w}$ wieku od 31 do 40 roku życia.

Wyniki częstości i testu chi ${ }^{2}$ różnic w poziomie odczuwanego stresu związanego ze śmiercią pacjenta a wiekiem przedstawia tabela 6. Tab. 6. Subiektywny poziom stresu badanych po śmierci pacjenta a wiek.



Wiek badanych różnicował subiektywne odczuwanie stresu po śmierci pacjentów $(\mathrm{p}=0,044)$. Badani najmłodsi wskazywali najczęściej, że stres jest średni lub niski; badani od 31 do 40 roku życia określili go jako średni lub wysoki; podobnie osoby do 50 roku życia

i 60 roku życia. U najstarszych wiekiem stres był niski. Wynik testu związku liniowego ukazuje, że poziom stresu wraz z wiekiem rośnie poziom odczuwanego stresu i odwrotnie $(\mathrm{p}=0,036)$.

Wyniki częstości i testu chi² różnic międzygrupowych między zadaniami i obowiązkami sprawiającymi największy problem w zawodzie pielęgniarki a wiekiem przedstawia tabela 7 . 
Tab. 7. Zadania i obowiązki stanowiące największy problem w zawodzie pielęgniarki a wiek.



Wiek różnicował odpowiedzi dotyczące zadań i obowiązków stanowiących największy problem zawodowy $(\mathrm{p}=0,002)$. Wśród osób najmłodszych najczęściej wskazywanym problemem była opieka nad umierającym pacjentem (40\%); badani w wieku od 31 do 40 lat wskazywali na konieczność informowania o śmierci (44\%), podobnie osoby od 41 do 60 lat. U osób najstarszych wiekiem wskazano na odpowiedź inne. 
Wyniki częstości i testu chi ${ }^{2}$ różnic $\mathrm{w}$ hierarchii wartości ze względu na stan cywilny przedstawia tabela 8 .

Tab. 8. Najważniejsze wartości a stan cywilny.

\begin{tabular}{|c|c|c|c|c|c|c|c|c|}
\hline & & & Stan cyn & & & & & Ogółe \\
\hline & & & $\begin{array}{l}\text { mężatk } \\
\text { a }\end{array}$ & panna & $\begin{array}{l}\text { Rozwiedzion } \\
\text { ya }\end{array}$ & $\begin{array}{l}\text { wdow } \\
\text { a }\end{array}$ & $\begin{array}{l}\text { wolny } \\
\text { związek } \\
\text { partners } \\
\text { ki }\end{array}$ & $\mathrm{m}$ \\
\hline Wartoś & zdrowi & $n$ & 31 & 13 & 12 & 3 & 1 & 60 \\
\hline $\mathrm{ci}$ & & $\%$ & $60,8 \%$ & $68,4 \%$ & $75,0 \%$ & $50,0 \%$ & $12,5 \%$ & $60,0 \%$ \\
\hline & rodzina & $n$ & 19 & 3 & 4 & 3 & 2 & 31 \\
\hline & & $\%$ & $37,3 \%$ & $15,8 \%$ & $25,0 \%$ & $50,0 \%$ & $25,0 \%$ & $31,0 \%$ \\
\hline & przyjaź & $\mathrm{n}$ & 1 & 2 & 0 & 0 & 4 & 7 \\
\hline & & $\%$ & $2,0 \%$ & $10,5 \%$ &, $0 \%$ &, $0 \%$ & $50,0 \%$ & $7,0 \%$ \\
\hline & pomoc & $\mathrm{n}$ & 0 & 1 & 0 & 0 & 1 & 2 \\
\hline & innym & $\%$ & ,0\% & $5,3 \%$ & ,0\% & ,0\% & $12,5 \%$ & $2,0 \%$ \\
\hline Ogółem & & $n$ & 51 & 19 & 16 & 6 & 8 & 100 \\
\hline & & $\%$ & $100,0 \%$ & $\begin{array}{l}100,0 \\
\%\end{array}$ & $100,0 \%$ & $\begin{array}{l}100,0 \\
\%\end{array}$ & $100,0 \%$ & $\begin{array}{l}100,0 \\
\%\end{array}$ \\
\hline
\end{tabular}

Z danych statystycznych wynika, że stan cywilny różnicował najważniejszą wartość wśród badanych. W przypadku mężatek, osób wolnych i rozwiedzionych najważniejsze było zdrowie; wdowy wskazały na zdrowie oraz rodzinę a osoby w wolnym związku partnerskim najczęściej cenił sobie przyjaźń. Różnice były istotne statystycznie $(\mathrm{p}=0,000)$.

Wyniki częstości i testu chi $^{2}$ badającego różnice między zmianą hierarchii wartości po śmierci pacjenta a stanem cywilnym badanych przedstawia tabela 9 . 
Tab. 9 Zmiana hierarchii wartości po śmierci pacjenta a stan cywilny.

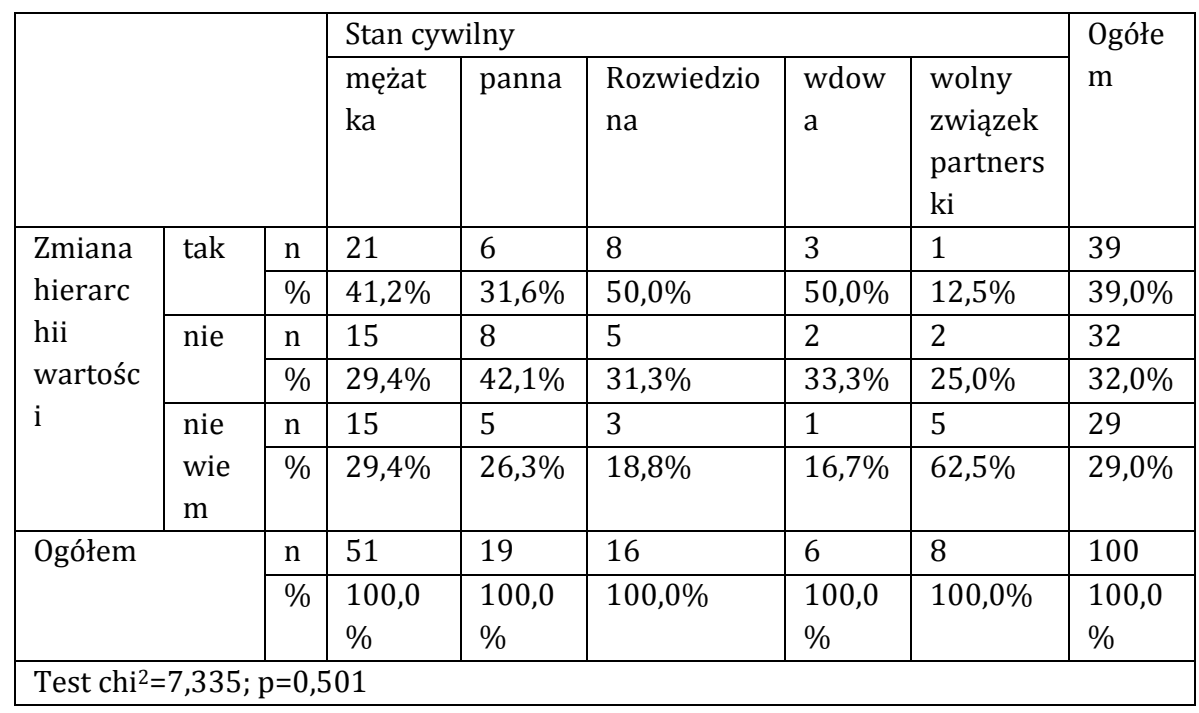

Nie wykazano istotnych różnic w zmianie hierarchii wartości po śmierci pacjenta a stanem cywilnym pielęgniarek/pielęgniarzy $(\mathrm{p}>0,05)$.

Wyniki częstości i testu chi ${ }^{2}$ różnic w hierarchii wartości ze względu na wykształcenie przedstawia tabela 10. 
Tab. 10. Najważniejsze wartości a wykształcenie.

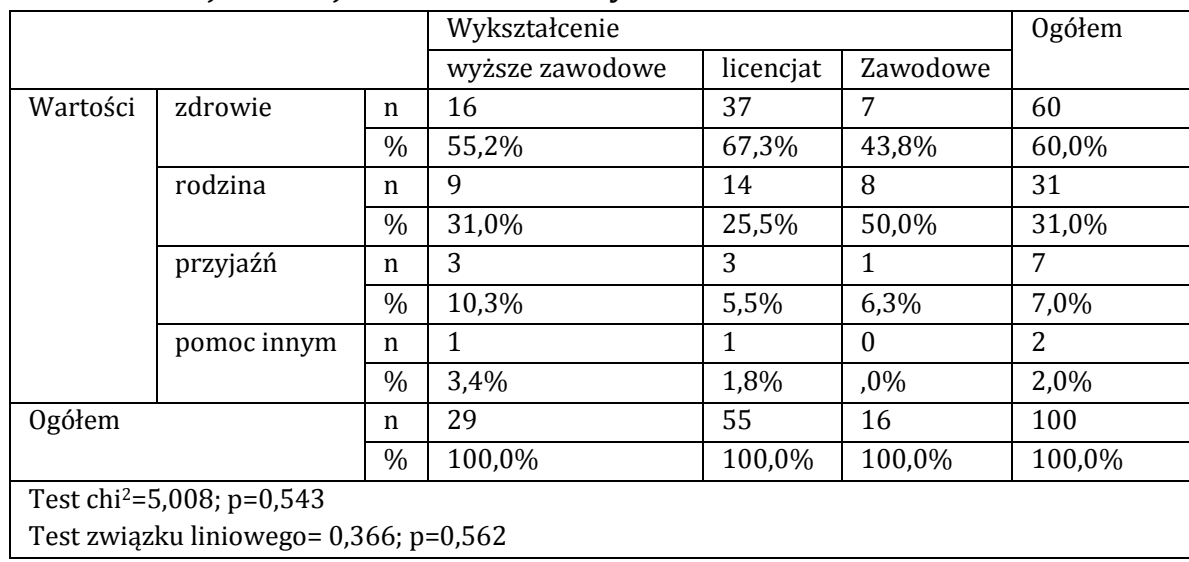

Wykształcenie respondentów nie różnicowały najważniejszej wartości w życiu $(\mathrm{p}>0,05)$.

Wyniki częstości i testu chi ${ }^{2}$ badającego różnice między zmianą hierarchii wartości po śmierci pacjenta a wykształceniem badanych przedstawia tabela 11 .

Tab. 11. Zmiana hierarchii wartości po śmierci pacjenta a wykształcenie.




Nie wykazano istotnych różnic w zmianie hierarchii wartości po śmierci pacjenta a wykształceniem pielęgniarek/pielęgniarzy $(p>0,05)$.

Wyniki częstości i testu chi ${ }^{2}$ różnic $\mathrm{w}$ hierarchii wartości ze względu na staż pracy przedstawia tabela 12 .

Tab. 12. Najważniejsze wartości a staż pracy.

\begin{tabular}{|c|c|c|c|c|c|c|}
\hline & \multicolumn{3}{|l|}{ Staż grupy } & \multirow{2}{*}{$\begin{array}{l}\text { Ogółe } \\
\text { m }\end{array}$} \\
\hline & & & poniżej 5 lat & od 6 do 25 lat & powyżej 25 lat & \\
\hline \multirow[t]{8}{*}{ Wartości } & \multirow[t]{2}{*}{ zdrowie } & $\mathrm{n}$ & 9 & 32 & 19 & 60 \\
\hline & & $\%$ & $69,2 \%$ & $62,7 \%$ & $52,8 \%$ & $60,0 \%$ \\
\hline & \multirow[t]{2}{*}{ rodzina } & $\mathrm{n}$ & 3 & 12 & 16 & 31 \\
\hline & & $\%$ & $23,1 \%$ & $23,5 \%$ & $44,4 \%$ & $31,0 \%$ \\
\hline & \multirow[t]{2}{*}{ przyjaźń } & $\mathrm{n}$ & 1 & 5 & 1 & 7 \\
\hline & & $\%$ & $7,7 \%$ & $9,8 \%$ & $2,8 \%$ & $7,0 \%$ \\
\hline & \multirow{2}{*}{$\begin{array}{l}\text { pomoc } \\
\text { innym }\end{array}$} & $\mathrm{n}$ & 0 & 2 & 0 & 2 \\
\hline & & $\%$ & , 0\% & $3,9 \%$ & , 0\% & $2,0 \%$ \\
\hline \multirow{2}{*}{\multicolumn{2}{|c|}{ Ogółem }} & $\mathrm{n}$ & 13 & 51 & 36 & 100 \\
\hline & & $\%$ & $100,0 \%$ & $100,0 \%$ & $100,0 \%$ & $\begin{array}{l}100,0 \\
\%\end{array}$ \\
\hline
\end{tabular}

Staż pracy $\mathrm{w}$ zawodzie nie różnicowało najważniejszej wartości badanych $(\mathrm{p}>0,05)$.

Wyniki częstości i testu chi² badającego różnice między zmianą hierarchii wartości po śmierci pacjenta a stażem pracy badanych przedstawia tabela 13 . 
Tab. 13. Zmiana hierarchii wartości po śmierci pacjenta a staż pracy.

\begin{tabular}{|c|c|c|c|c|c|c|}
\hline & & & Staż. grupy & & & Ogółem \\
\hline & & & $\begin{array}{l}\text { poniżej } 5 \\
\text { lat }\end{array}$ & $\begin{array}{l}\text { od } 6 \text { do } 25 \\
\text { lat }\end{array}$ & $\begin{array}{l}\text { powyżej } 25 \\
\text { lat }\end{array}$ & \\
\hline Zmiana & tak & $\mathrm{n}$ & 3 & 22 & 14 & 39 \\
\hline hierarchii & & $\%$ & $23,1 \%$ & $43,1 \%$ & $38,9 \%$ & $39,0 \%$ \\
\hline wartości & nie & $\mathrm{n}$ & 10 & 12 & 10 & 32 \\
\hline & & $\%$ & $76,9 \%$ & $23,5 \%$ & $27,8 \%$ & $32,0 \%$ \\
\hline & nie wiem & $\mathrm{n}$ & 0 & 17 & 12 & 29 \\
\hline & & $\%$ &, $0 \%$ & $33,3 \%$ & $33,3 \%$ & $29,0 \%$ \\
\hline Ogółem & & $n$ & 13 & 51 & 36 & 100 \\
\hline & & $\%$ & $100,0 \%$ & $100,0 \%$ & $100,0 \%$ & $100,0 \%$ \\
\hline $\begin{array}{l}\text { Test } \text { chi }^{2}= \\
\text { Test związ }\end{array}$ & $45 ; p=0$ & U, & & & & \\
\hline
\end{tabular}

Wykazano istotną różnice $\mathrm{w}$ zmianie hierarchii wartości po śmierci pacjenta a stażem pracy $(\mathrm{p}=0,005)$. $\mathrm{Z}$ analizy wynika, że najmłodsi stażem nie zauważyli zmian $\mathrm{w}$ hierarchii wartości po takim wydarzeniu, a zmiana taka następowała $\mathrm{u}$ większego odsetka badanych o stażu pracy od 6 do ponad 25 lat.

\section{Dyskusja}

Śmierć zawsze łączy się z negatywnymi i nieprzyjemnymi uczuciami, to ból, strach, poczucie straty. Dziś ludzie coraz częściej „odchodzą" w szpitalu, gdzie obecna jest pielęgniarka i jej opieka. Śmierć pacjenta jest stałym elementem pracy $w$ tej grupie zawodowej i jest dużym czynnikiem stresogennym. Warto wskazać, że pielęgniarki należą do grupy pracowników, którzy najczęściej w praktyce zawodowej stykają się ze śmiercią w porównaniu z resztą społeczeństwa [8]. W badaniach własnych postawiono sobie za cel analizę modelu postaw pielęgniarek wobec umierania i śmierci.

Badania własne ukazały, że opieka nad umierającym pacjentem dla $27 \%$ ankietowanych stanowi problem, ale największą 
trudnością jest konieczność informowania bliskich pacjentów o ich śmierci (39\%). Z badań Gołębiak wynika, że 17,4\% badanych pielęgniarek odczuwa strach przed rozmową $\mathrm{z}$ osobą umierającą, a 13,9\% obawia się śmierci pacjenta. Zdarzają się także przypadki, w których pielęgniarka unika rozmów i kontaktów z umierającym pacjentem $(10,4 \%)$ [9]. W badaniach własnych płeć ankietowanych nie różnicowała największych problemów w zawodzie. Brak wpływu płci na postawy wobec umierania i śmierci pacjenta wykazały także badania Gołębiak [9]. Wykazano jednak, że istotną zmienną różnicują trudności zawodowe $\mathrm{w}$ postaci opieki nad umierającymi pacjentami był wiek $(\mathrm{p}=0,002)$. Im osoby młodsze tym opieka ta stanowiła dla nich większą trudność (40\%), zaś u osób w wieku od 31 do 60 lat największą trudność stanowiło informowanie bliskich o śmierci pacjenta (od 38,5\% do 44\%). Badania nie wykazały różnic w trudnościach zawodowych a stanem cywilnym, stażem pracy i wykształceniem ankietowanych $(p>0,05)$. Inaczej $w$ badaniach Gołębiak, w których wykazano, że istnieje zależność między wykształceniem a gotowością do towarzyszenia umiejącemu pacjentowi. Im wykształcenie wyższe, tym większa gotowość do niesienia pomocy [9].

W badaniach Nyklewicz częsty kontakt pielęgniarek z pacjentami umierającymi i ich rodzinami sprawia, że są one narażone na przeżywanie stresu oraz destrukcyjne działanie negatywnych emocji [10]. Natomiast na występowanie stresu w pracy zawodowej związanej z umieraniem pacjentów wskazało 80\% ankietowanych $\mathrm{w}$ badaniach Zawiślak [11]. W badaniach własnych pielęgniarki oceniły swój stres związany ze śmiercią pacjenta jako średni (57\%) lub wysoki (32\%). W badaniach Gołębiak umieranie i śmierć pacjentów powodują problemy ze snem (33\%), zmęczenie $(17,4 \%)$, niechęć do pracy $(17,4 \%)$ i napięcie emocjonalne $(14,8 \%)[9]$. 
W badaniach własnych poziom odczuwanego stresu po śmierci pacjenta różnicował wiek pielęgniarek $(\mathrm{p}=0,036)$. Wykazano także dodatni związek między wiekiem a poziomem stresu ( $\mathrm{p}=0,036)$. Oznacza to, że wraz ze wzrostem wieku badanych rósł poziom stresu odczuwanego po śmierci pacjenta. Wykazano, że poziom stresu pielęgniarek po śmierci pacjenta zwiększa się wraz ze stażem pracy $(\mathrm{p}=0,026)$. Stan cywilny, płeć, wykształcenie ankietowanych nie różnicował poziomu odczuwanego stresu po śmierci pacjenta $(\mathrm{p}>0,05)$.

Ankietowanym pielęgniarkom po śmierci pacjenta towarzyszy najczęściej smutek (65\%), rzadziej niechęć do pracy (16\%) czy apatia (14\%). Podobnie było w badaniach Zawiślak, gdzie do najczęstszych emocji należał smutek (39,3\%), a w dalszej kolejności złość $(21,4 \%)$. Nieliczni wskazywali także na pojawiającą się w badaniach własnych niechęć do wykonywanego zawodu, strach oraz przygnębienie. Większość pielęgniarek po śmierci pacjenta odczuwa negatywne emocje, jak smutek, żal i współczucie [11]. Niedojad w swoich badaniach wskazał, że emocjom towarzyszącym pielęgniarkom postracie pacjenta jest współczucie i smutek (91\%), żal i przygnębienie (70\%).[12]. W badaniach Gołębiak wykazano, że reakcją na obcowanie ze śmiercią pacjenta jest lęk $(24,3 \%)$ i współczucie $(17,4 \%)$. Pojawiają się także takie emocje negatywne, jak żal $(13,9 \%)$, bezsilność $(6,1 \%)$. Z kolei najczęstszą reakcją emocjonalną po śmierci pacjenta jest lęk przed stratą bliskiej osoby (35,7\%), a u 11,8\% lęk przed śmiercią w ogóle.[9]. Analizy Gaworskiej- Krzemińskiej i wspólników wskazały zaś, że emocjami towarzyszącymi pielęgniarkom po śmierci pacjenta była najczęściej bezsilność (67\%) i współczucie (33\%) [13].

Stres i obciążenia fizyczne powodują zmianę podejścia pielęgniarek do podstawowych spraw egzystencjalnych, często powodują uczucie lęku o własne życie czy życie osób najbliższych 
[14]. Podobnie w badaniach własnych, w których wykazano, że śmierć pacjenta u 39\% badanych powoduje zmiany w dotychczasowej hierarchii wartości. Stwierdzono, że zmienną różnicują zmianę hierarchii wartości po stracie pacjenta jest wiek pielęgniarek. Zmiana ta następowała częściej u badanych w wieku od 31 do 60 roku życia, a najrzadziej u najmłodszych wiekiem (poniżej 30 lat). Zmienną różnicującą był także staż pracy, wykazano bowiem, że im staż pracy dłuższy tym więcej badanych o stażu pracy od 6 do 25 lat $(43,1 \%)$ i powyżej 25 lat (38.9\%) zmieniało swoją hierarchię wartości. Stan cywilny, płeć i wykształcenie nie różnicowały zmiany hierarchii wartości po śmierci pacjenta. Fakt, że śmierć pacjenta to zjawisko ważne i niezapomniane potwierdzają także wyniki badań Śleziony i Krzyżanowskiego w których większość respondentów (64 osoby53\%) stwierdziło, że pamięta swoje pierwsze zetknięcie się ze śmiercią pacjenta, a śmierć pacjenta, była ważnym i niezapomnianym przeżyciem dla $58 \%$ ankietowanych (70 osób). [7]. Pielęgniarkom $\mathrm{w}$ takiej sytuacji towarzyszy także obawa przed śmiercią według badań De Walden-Gałuszko i Ciałkowskiej-Rysz[15]. Badani Gołębiak wskazują, że śmierć pacjenta powoduje, że badani sami przygotowują się do śmierci własnej (24,3\%) i skłania ich do refleksji nad życiem $(17,4 \%) \cdot[9]$.

\section{Wnioski}

1. Płeć nie różnicuje postaw pielęgniarek wobec umierania i śmierci pacjenta.

2. Wiek różnicuje postawy wobec umierania i śmierci pacjenta. Im osoby młodsze tym większą trudność stanowi dla nich opieka nad umierającym pacjentem, im osoby starsze, tym częściej deklarują, że nie stanowi to dla nich problemu. Jest on także istotną zmienną różnicują poziom odczuwanego stresu przez 
pielęgniarki po śmierci pacjenta. Im osoby starsze tym lepiej radzą sobie ze stratą. Ponadto wiek okazał się czynnikiem istotnie różnicującym zmianę hierarchii wartości po śmierci pacjenta wśród personelu medycznego. Zmiana taka następowała częściej wraz ze wzrostem wieku ankietowanych.

3. Stan cywilny nie różnicował trudności pracy pielęgniarek w postaci opieki nad osobą umierającą i informowania bliskich o śmierci pacjenta.

4. Wykształcenie nie różnicowało trudności pracy pielęgniarek w postaci opieki nad osobą umierającą i informowania bliskich o śmierci pacjenta.

5. Staż pracy nie różnicował trudności pracy pielęgniarek w postaci opieki nad osobą umierającą i informowania bliskich o śmierci pacjenta. Wpływał on jednak dodatnio na poziom stresu pielęgniarek po śmierci pacjenta. Im osoby starsze stażem tym większy odczuwały poziom stresu. Ponadto staż pracy różnicował zmianę hierarchii wartości po śmierci pacjenta. Im staż pracy dłuższy tym częściej strata pacjenta powodowała zmiany w wartościach ankietowanych.

\section{Zalecenia dla praktyki pielęgniarskiej}

Podsumowując niniejszą pracę należy zaznaczyć, że kontakt pielęgniarek z pacjentami umierającymi naraża na stres, negatywne emocje, duże obciążenie psychiczne. Zdolność współczucia, odpowiednie przygotowanie pielęgniarek ma duży wpływ na zapewnienie zmniejszenia cierpienia i godnego umierania pacjenta.

\section{Bibliografia / Bibliography:}


1. Arendt-Dziurdzikowska R. Możesz odejść bo cię kocham 0 śmierci, pożegnaniach i nowym życiu, Wydawnictwo Zwierciadło Sp. z o.o. Warszawa 2012:3-5, 8-9, 34-36.

2. Becler R. Ewolucja operacyjnej definicji śmierci człowieka, Prawo i Medycyna 2015, nr 2: 3-7.

3. Orzechowska A., Gałęcki P. Zaburzenia psychosomatyczne w ujęciu w ujęciu terapeutycznym, Wydawnictwo Contino, Wrocław 2014: 7-10.

4. De Walden-Gałuszko K., Kartacz A. Pielęgniarstwo w opiece paliatywnej i hospicyjnej, PZWL, Warszawa 2010: 77-79.

5. Baranowska M. To jest wasze życie. Być sobą w chorobie przewlekłej, Wydawnictwo Czarne, Wołowiec 2011: 3-5.

6. Rozwadowska E. Samoocena postaw pielęgniarek wobec śmierci, Pielęgniarstwo XXI wieku, 2010:1-2,43-49.

7. Śleziona, M. Krzyżanowski D. Postawy pielęgniarek wobec śmierci i umierania. Pielęgniarstwo i Zdrowie Publiczne, nr 3, 2011: 217-223

8. Krajewska-Kułak E., Nyklewicz W. W drodze do brzegu życia, A.M., Białystok 2016: 5-7, 9-10.

9. Gołębiak I., Szczepaniak R., Łazowa A., Dykowska G. Postawy pielęgniarek wobec śmierci pacjenta. Pielęgniarstwo w Opiece Długoterminowej, 2019, vol. 4: 34-44.

10. Nyklewicz W., Krajewska-Kułak E. Śmierć a emocje pielęgniarek doniesienia wstępne. Problemy Pielęgniarstwa. 2008, nr 3 (16): 248-254.

11.Zawiślak A. Postawy pielęgniarek hospicyjnych wobec śmierci własnej i bliskich osób. Pielęgniarstwo i Zdrowie Publiczne, 2016, nr 3: 197-203. 
12. Niedojad K., Rybka M., Rezmerska L., Slusarz R. Śmierci umieranie wopinii personelu pielęgniarskiego. Pielęgniarstwo w opiece długoterminowej, $2016 \mathrm{nr}$ 3: 12-

13. Gaworska-Krzemińska A. Postawy i emocje towarzyszące pielęgniarkom w opiece nad pacjentem umierającym. [W:] E. Krajewska-Kułak, M. Szczepański, C. Łukaszuk, J. Lewko (red.), Problemy terapeutycznopielęgnacyjne od poczęcia do starości. Tom II. Wydawnictwo Akademii Medycznej w Białymstoku, Białystok 2017: 12-15.

14. Dębska G., Merklinger-Soma M., Cepuch G. Emocje jako element postawy towarzyszący pielęgniarce $\mathrm{w}$ kontakcie $\mathrm{z}$ pacjentem umierającym, Pielęgniarstwo XXI wieku 2010, nr 1-2: 65-70.

15.De Walden-Gałuszko K., Ciałkowska- Rysz A. Medycyna Paliatywna. Redakcja naukowa, Wydawnictwo PZWL 2015: 123-128. 